\title{
Social Memory Deformations in Locus of Relationship between the Past and Present
}

\author{
Vagif Deyrushevich Bayramov ${ }^{1}$, Vladimir Aleksandrovich Kirik², Aues Muhamedovich Kumykov ${ }^{3}$ \& Svetlana \\ Aslanovna Lyausheva ${ }^{4}$ \\ ${ }^{1}$ Moscow State University of Humanities and Economy, Moscow, Russian Federation \\ ${ }^{2}$ Institute of Sociology and Regional Studies, Southern Federal University, Rostov-on-Don, Russian Federation \\ ${ }^{3}$ Kabardino-Balkarian State University, Nalchik, Russian Federation \\ ${ }^{4}$ Adyghe State University (Department of Philosophy and Sociology), Rostov-on-Don, Russian Federation \\ Correspondence: Vladimir Aleksandrovich Kirik, Pushkinskaya street, 160, Rostov-on-Don, 344005, Russian \\ Federation. Tel: 78-6-3264-1755. E-mail: infoippk@sfedu.ru
}

Received: March 30, 2015 Accepted: April 20, 2015 Online Published: May 14, 2015

doi:10.5539/res.v7n7p201 URL: http://dx.doi.org/10.5539/res.v7n7p201

\begin{abstract}
The article covers the processes of social memory transformation in the Russian society. The authors determine its deformation in locus of relationship between the past and present. It is emphasized that the distinction between history and historical memory as an integral part of social memory reside in how to interpret the possibility of studying the past time. Deformations of social memory in locus of relationship between the past and present relate to the fact that memory is selective and often personified in nature, when evaluation of specific historical figures forms certain impressions, judgments, and opinions.

The article shows paradoxical combination of the past and present, significance of the past events for orientation in the present. The authors argue that historical memory is a powerful, active phenomenon that has an impact on people's behavior equal to the influence exerted by estimate of their current economic situation, their insecurity and despondency in this transitional period. However, the "constructed historical past" in the modern Russian society remains unsteady. Controversies with regard to the historical past result from the absence of consistency in opinions on the desired future of the country. Historical narrative of power is forming preconditioned by its political pretensions and ideological motivations.
\end{abstract}

Keywords: social memory, the past, images of the past, perception of the past, perception of the present, social amnesi

\section{Introduction}

\subsection{Problem Definition}

Cognitive relation of social knowledge to its subject matter is expressed in a form of perception, which establishes mediated relationship of knowledge with its subject matter, since it exists, when the subject matter is not yet determined. Consequently, the historic perception being the primary subject of this research is related not to the product of feeling, but to the denotation ability. These subjects are mastered only when they are comprehensible. The history might be understood as a sort of essence, something we never stumble upon and that does not actually exist.

We know the essence of the history; furthermore, we recreate and reconstruct this essence, but cannot say that the product of creation actually exists. We do not know how the history exists. The essence as a basis is the "form" and the "reason", i.e. it is a substance. The history comes true through the thought—in universal. Formally, predication of the essence existence occurs in the thought - the history substance. In other words, the history represents such a process of reconstructing the "essence", in which the predicate of existence is attributed to the recreated essence in a form of the thought as a subject of history (Podlipskiy, 1997).

The difference between history and historical memory as an integral part of social memory, to our opinion, resides in the way of interpreting the possibility to perceive the past time. Deformations of social memory in locus of relationship between the past and present are associated with sociocultural processes taking place in modern world. 
D. A. Anikin presumes that "the main function of social memory is self-identification of a certain community by emphasizing its dissimilarities from other communities and mitigation of possible controversies within such a community." Effective and adequate ways of memory fixation may outlive even a community, where such memory type was functioning, becoming the subject of specific historical research; otherwise, historical memory may disappear leaving nothing but pieces and fragments (Anikin, 2008).

Historical memory is not only relevant in nature, but also selective. The past as a reservoir of ideas and cases may become an important tool for understanding the present. Historical parallels will not help to predict the future, since they are valuable as symptoms of similar social processes invariably occurring at different times in various countries and, as a rule, having varying scenarios depending on circumstances.

Social memory deformations in locus of relationship between the past and present are accompanied by formation of myths and social mythogenesis.

\subsection{Literature Review}

The largest contribution to the study of social memory in social and humanitarian sciences was made by E. Durkheim's ideas, who wrote about collective representations as the body of knowledge, opinions, and behaviors being the products of social evolution (Durkheim, 1997). In continuation of Durkheim's ideas, M. Douglas (Douglas, 1986) and P. Connerton (Connerton, 2009) also wrote about correlation of memory and social community. The works of J. Assmann (Assmann, 2000) devoted to the study of social characteristics of individual and social memory are also worth noticing.

Researchers mentioned the presence of critical social demand for the past and its evaluation and interpretation. The British researcher D. Lowenthal addressed the issues related to perception of the past. The scientist examined the social and cultural role of the past, exploring such phenomena as nostalgia and fear of the past, paying attention to the problems of perception of the near and distant past (Lowenthal, 1998). Erll (2008) analyzed the nature of intermedial dynamics of cultural memory.

To our opinion, the conclusion of A. Kleitman is very important: oblivion, as a cultural phenomenon, is a form of representation of the past in the present, and manifests itself as one of temporality modes of the human and society existence (Kleitman, 2009).

Scientific works of the Russian sociologist Zh.T. Toshchenko play an important role in research of this problem. He introduced the concept of "mankurtism", which stands for historical amnesia, various forms of falsification of the past, ignoring previous cumulative spiritual wealth, misinterpreting historical events and processes, distorting the history in favor of chauvinistic and xenophobic views (Toshchenko, 2012).

\section{Methodology}

Social memory is a complex phenomenon requiring transdisciplinary and multiparadigmatic approach. The social memory phenomenon requires the use of tools attributed to the history as science, which studies the laws of the past events preservation in historical memory, as well as various aspects of addressing such memory by political power and society. Social psychology analyzes social memory in terms of psychological features of representation of socially significant events in individual memory. Sociologists refer to social memory in terms of applied research, usually identifying the place of various events or historical figures in social memory.

The methodological basis of the study consists in the principles of social philosophy as a transdisciplinary scientific discipline providing theoretical generalization of private scientific research results, as well as research approaches, such as analysis and synthesis, induction and deduction, abstraction and typification, principles of studying social phenomena in terms of classical and postnonclassical scientific paradigms.

The following theoretical approaches had significant impact on the author's methodology: a) the constructivist approach to the social amnesia analysis including the study of the issues of "invention" of memories, rituals, and traditions as the means of social control, legitimation of power and preservation of identities, as well as politicization of memory and "memory policy"; dependence of images of the past from current interests of the ruling elite; b) the concept of "social memory"; c) the theory of cultural sociology and the concept of increasingly complex dynamic of social meanings, developed in line with neo-functionalism.

\section{Results}

Various philosophical sources turn attention to the fact that the specific character of mythological consciousness varies depending on the features of a society existence. This form of consciousness starts to dominate at the beginning of crisis, transitional situation; furthermore, an interest within the framework of this form of consciousness is rising not only to the irrational, but also to the archaic ways of reality comprehension. 
According to P. Bourdieu, when new myths are generated due to the crisis, they give occasion to an unusual discourse. When it is not possible to overcome a chaotic state brought by crisis, the society returns to the ways of reality comprehension based on mythological consciousness. Archaism of consciousness in transitional periods, in the initial phase of civilization collapse, is a natural, scarcely ever realizable, unreflected response to the challenge of the civilizational process (Pomortseva, 2009).

One of the significant features of social memory deformation is restoration of the Stalin's myth. According to D. Dondurey, there is no civilized order for deconstruction and destruction of the myth about Stalin in Russia. The "Super-Stalin" PR project remains in effect reproducing "neo-feudalism basics" in mass ideological consciousness. Therefore, today $51-78 \%$ of Russians believe in a positive role of "Comrade Stalin" in the history (Dondurey, 2010). Herewith, B. Dubin finds correlation with "the syndrome of unenchanted past" (Dubin et al., 2006).

According to D. Gudkov's estimates, "the Stalin's cult is not reproducible, but the appeal to this character remains in a form of passive criticism of the present for strata and groups deprived of social resources. This is a distinct complex of national inferiority associated with the traumatic experience of the fall of the Soviet Union, a sense of shame for losing the country's symbols of grandeur, for disclosure of carefully concealed "military secrets" to the entire world: despite its nuclear-missile power, Russia is a poor, hopelessly backward country with undeveloped social infrastructure and downtrodden population humiliated by the authorities." The myth about Stalin as the greatest leader, turning underdeveloped peasant Russia into a powerful industrial state, serves for the needs of mass consolation and eradication of the national inferiority complex (Gudkov, 2008).

Social myth is understood as the basis of social organization, independent of the prevailing sociocultural paradigm, but affecting social organization of the society (Bloshenko, 2011). In turn, updating the sphere of concepts is closely associated with significant changes in the outlook of an individual, with the ideological agony, transformation of mass consciousness that occur in the background and under the influence of changes in socio-economic life of Russia. Reflections fixing mental transformation at the worldview level are largely predetermined by derivational criterion of conceptual tension responding to the complexity of mutations in the essential core of the mass consciousness - the system of value orientation.

In the context of actualization of mythological models, the ordinary consciousness forms a common mental map of "the past", which is in demand under conditions of massification of historical concepts and their adaptation to the normative-power format of the unified media-information space. That is a set of "empty" formulas and explanatory schemes of consolidation, simulation of positiveness manifests through reinstatement of the bygone grandeur of Russia by restoring and collecting all the best of "our history". A positive image of the future is conceived in terms of imperial views (Zvereva, 2005).

Social mythogenesis in locus of relationship between the past and present is interlocking with the technologies of social manipulation. Conventional sociocultural reality resides in expansion of administrative influence for the purpose of political mobilization followed by introduction of new information and communication technologies used in everyday political practice in the circumstances of an information society formation. The substantive element of the methods of political influence, as a means of political experience transfer, resides in the fact that political interaction relies upon different cultural "codes" and models determined by the level of communication exchange.

Famous domestic sociologist Zh. T. Toschenko, based on his concept of mankurtism, emphasized several forms of this phenomenon. One of the forms was the intentional misrepresentation (falsification) of the past, when historical events, the life and deeds of politicians (and other historical figures) are altered beyond recognition, and their actions, the causes and consequences of events are deprived of any meaning and credibility. Another form is the creation of fictional pseudo-events, pseudo-processes, and quasi-historical persons (Toshchenko, 2010).

Deformations of social memory in locus of relationship between the past and present are predetermined by painful experience of the past. According to M. McAuley, it should come as no surprise that the governments in the twentieth century were extremely reluctant to public discussion of dismal episodes of the recent past, no matter who was the object of reprisals or other harassments, either their own or foreign citizens. Democratic governments are no exception (McAuley, 2011).

Painful experience of the past and unwillingness to criticize it provoke the issue of perversion of history.

Speaking at the plenary session of the Moscow City Council of Veterans on April 18, 2012, V. I. Dolgikh said that the issue of history falsification is not new, and veterans have always been committed to fight against this evil, intensively disseminated for decades in textbooks, television channels, the western propaganda, and 
homegrown renegades. Falsification and fight against counterfeiters was aggravated, then decayed with the change of the political situation, uprise of new oracles or newly minted "researchers" and "pioneers", requiring reassessment of the events, the role of historical figures of our state. Each of the following periods had its own specific falsification pattern: the Soviet period, perestroika, and dissolution of the Soviet Union. We live in a special time. This question is of immediate interest nowadays. The world community generates global ideas often turning into planetary scale menace. The existing structure of the global economy is on the threshold of collapse. Endeavors of the known forces to create a unipolar world and prolong dollar domination stymied global economy development. A series of financial and economic crises descend upon humanity. In the first instance, the USA, as an aspirant to global power, openly declares to defend its interests in every corner of the globe by all means, regardless of the attitude of other nations and people towards such policy. In addition, the USA actively implements this policy.

Once again, in the world history Russia makes a stand against an aggressor. That is why those standing on the other side of the front initiate a mission to prevent strengthening of the socio-economic, political, and defense potential of Russia. All political and economic means are applied to achieve these purposes, but one of the hot spot of hostile activity against us is undermining and destruction of the spiritual, moral, and patriotic potential of Russia, its cross-national unity. Russia's enemies never hide their goal to eradicate moral principles and patriotic beliefs of the Russian people and of our young generation in the first instance. Falsification of historical facts and events, their distortion and denial plays an important role in this strategy. These forces act in accordance with well-planned and thoroughly elaborated program. In their time, understanding impossibility of a direct attack at the Soviet Union, being unable to refute the strong economic growth of the USSR, achievements of science, development of education and culture in the postwar period, counterfeiters had to focus on the mistakes made in the period of socialist construction and transformation of such mistakes and difficult periods into the Soviet history landmark. And political repressions condemned by the Party and the Soviet Government were exaggerated and transformed into a single picture of the Soviet life. After the fall of the Soviet Union, counterfeiters of history proceeded to total denigration of the Soviet history. It is important not to keep clear of falsifications and react swiftly (Dolgikh, 2012).

Nevertheless, the discussion on relationship and correlation of historical memory and historical amnesia inevitably raises the question of today's importance of these subjects from political or civil perspective. Of course, the relationship between the past and the present is much more complicated than it might be considered by people like V. I. Dolgikh or his organization. In any case, only civil liability for their own history, but not the great achievements and major catastrophes, make people a nation in the true sense of the word, i.e. the society of citizens. We cannot create a society of citizens without recognizing our past.

The experience of recent history shows that, for instance, different societies overcome the traumas of World War II in different ways, but it is possible to identify some general patterns of experience of the past. At the end of World War II, the first short public reaction (which was absent in some countries) was followed by a period of amnesia in both winner countries and those who had lost the war or remained neutral. In Germany, France, Italy, and Austria, many of those convicted of war crimes stayed at home. The history of fascism or collaborationism period remained underexplored, while schoolteachers just taught history preceding the "difficult period" and stopped there. Admission of war crimes and discussion in this regard began later: in the 1960's in Germany, in the 1970's in France and Italy (fascism, war, and persecution of Jews appeared in Italian textbooks only in 1997), Austria and Switzerland started to discuss these topics only in 1980's. In all countries, political interests (politicians and influential social groups) and instantaneous political climate determine inclusion of the "darkest chapters" into historical narrative. However, if the leaders prefer to remain silent, what may induce rethinking of the past? Experience of countries that survived World War II testifies that the most important factor is the change of generations.

Revision of emotionally "convenient" representations occurs only with the advent of a new adult generation, who have not experienced war traumas. However, the dedicated actors may vary in different countries. In order to start revising the darkest chapters of history, the victims have to gain sufficient support of the community and achieve certain level of organization to demand immediate actions from a new government under appropriate circumstances. Therefore, neither an independent legal system and democratic election, nor the level of mass media and academic freedom may guarantee that a society or government is willing to overcome the dark past.

Democratic, constitutional states of Europe were "open" and "democratic" during the entire period, when the events that took place during the World War II were consigned to oblivion; these countries remained the same when the veil of amnesia fell. Democracy, independent judiciary, and freedom of speech in the US have a long history, but public discussion about slavery started not so long ago. In the 1960s, the United States has achieved 
tremendous success in destroying the foundations of racial discrimination not because of the belated confession of the horrors of slavery, but only because of the civil rights movement. Freedom of speech (in mass media and academic circles) is an essential prerequisite of an open, public discussion of dark spots in history, while the key actors here are politicians who want to win election, but that is not enough for taking action on revising the past. For many citizens of the country, not just for its leaders, it is more comfortable to remain unaware or forget the history.

In Russia, the main task of the government is to ensure control over the political and economic resources of the country and strengthen the role of Russia in the international arena. However, like other heads of state, Putin and Medvedev seek to strengthen their legitimacy. However, political leaders are not trying to create structures, which might help them to reflect and represent diverse and sometimes contradictory beliefs, loyalties, and aspirations of citizens. Therefore, the leaders have the only opportunity: build their legitimacy on the premise that they are the successors of the Russian tradition of a strong state defending the territory against external threats.

At a time when the Russian authorities retain the traditional Russian political model, where the state reigns supreme over the society, Stalin's personality, as the leader of the country that defeated Nazi Germany in particular, overshadows all other events. The Great Patriotic War remains a major milestone of a patriotic history, but a war only cannot fill the entire period from 1917 to 1953. Stalin's contribution to the victory may be successively revised; however, his role as an organizer and originator of mass repressions that continued until his death is not subject to revision under any circumstances. Evidence is too obvious. This topic remains relevant both at the domestic level and in the international community. Repressions and Stalin's role in them have to be admitted, and then the other aspects of the Soviet history will find their true value. Even if to judge from the pragmatic position of the country's leaders, this pace of developments could have beneficial effects.

According to A. V. Svyatoslavsky, the "culture of commemoration" is the culture of perpetuation appealing both to the images of the past and contemporary reality, which in the words of M. Halbwachs is encased by "memory frames" featuring specific cultural discourse. Finally, the culture of commemoration serves for transfer of socially significant values from the past to the future. The concept of commemoration culture is directly related to the historical communication, as well as the concepts of cultural experience and cultural heritage. Investigating the processes of conscious perpetuation, we get information on the views of the past, present, and future of the culture initiating a certain act of commemoration (Svyatoslavsky, 2012).

In its turn, effectiveness of commemorative practices is contingent upon the purposeful activity of social environment agents, represented both by individuals on the opposite poles of the political spectrum, and by social groups. Different interpretation strategies chosen by social groups result in formation of heterogeneous environment of social memory.

Efforts to preserve social memory and prevent its distortions were quite evident in the activities of dissidents during the Soviet era.

Every society invents relevant forms of discontent manifestation and accumulation. The Soviet society discovered such a specific form as the dissident movement. Dissidents did not raise a question of overthrowing the established order, since they negated violence and understood that it is impossible to do that using internal forces.

Their words were their deeds. They protested against the general situation within the society. Dissidence became a steady and significant phenomenon of the Soviet reality. Active resentment with regard to the existing order within the country and pursuit of freedom and human rights gave confidence in the renowned unity of this social phenomenon. It seems like dissidents empirically found the most acceptable ideological form - they became a tender conscience of the Soviet society.

In 1957-1958, social illusions caused by exposure of the "cult of personality" at the 20th Congress of the Communist Party and the myth of liberalization, on the one hand, as well as the difficulties of adapting to a new political interpretation of the recent past, on the other hand, were superimposed on the society's assessment of oppositely oriented political events.

In the first instance, it was a "battle for history" and democratization of public life. Estimates of the past events announced at the 20th Congress clearly proved to be insufficient for many thoughtful people. However, freethinking was beyond the scope of interest of the Party leaders. Political persecution started with building the cases against Brodsky, Sinyavsky and Daniel, Ginzburg and Galanskov. Many people understood all of this as a return to Stalinism.

The bearer of deformed social memory in post-Soviet Russia was a "Soviet person." 
Opinion poll within the framework of the "Soviet person" project took place in summer 2008. According to L. Gudkov, the purpose of this opinion poll was to determine what remains of the ideological models 60-70 years after the beginning of their enhanced implementation into the public consciousness, and what the social and historical consequences of reproducing this type of person, as well as prospects of the society, where such type of person becomes dominant, are. The image of a "Soviet person" in the course of formation and establishment of the Soviet system included an indispensable concept of a "controlled person" (by the Party, government, and authorities at all levels), but not a person controlling the power and its leaders. Thereby, people accepted the principle of human nature asymmetry echoing earlier traditional views of estates system. In addition, the Soviet person was a "new person", different from people of the past, who had lived, let us say, before the revolution, and from those living in other countries. This person is "special". The main difference of this person lies in the fact that he is "conscious." This kind of conscience is limited to submissive obedience to the orders of authorities. It is not necessary to demonstrate personal commitment to the authorities (ideals of "socialism" or "party", etc.), but at least one should not express disapproval with regard to the general opinions, top-down commands, and propaganda. This person admits any possible policies of the authorities without open resistance.

Historical consciousness often manifests itself as a comprehensive sense of a world and "finding oneself" in the historical flow of time.

S. A. Korolev noticed that history did its job very slowly. The power space and social environment transformed by the power in accordance with its ideas and interests remain quite extensive. People remain imperfect, intellectually and mentally vulnerable. Symbols and legends can suppress the ability for rational, logical thinking in the public consciousness. Perhaps, this relates to Russia more than to any other European country. The past is still used to justify current interests (Korolev, 2005).

According to O. A. Solopova, history turns into a powerful political and ideological instrument, when description of the past associated with collective memory provides important characteristics of the political discourse. Thus collective memory affects social reality, at least in two ways: 1) it provides a society model as a reflection of needs, problems, fears, mentality and expectations; and 2) it offers a society model as a program, defines social experience, articulates the values, goals, cognitive, affective and moral guidance for implementation of this program. In this regards, the past is represented as a certain transformed version of the present (Solopova, 2006).

The US political expert and historian T. Sherlock compares attitudes of Russia and the United States to their unsightly past.

He writes that Russia and the United States often criticize each other for manipulation of history, for endeavors to embellish the events of the past and ignore the unsightly phenomena. Indeed, the history of the United States often appears in the form of a "simplified morality" to help young citizens fit into the dominant political and socio-economic order. However, being the richest and the most powerful country in the world, the USA is slowly but progressively getting rid of the triumphalist and nationalist presentation of its history. Similar processes occur in Western Europe, but for other reasons and much faster. The First and Second World Wars, as well as decolonization, had a profound impact on Europeans' vision of themselves and their past. Hypernationalism and chauvinism, which imbued the schoolbooks of the 19th and early 20th century, are gone.

In Russia, when V. Putin came to power, the issued textbooks offered even more ambiguous assessment of the past events. However, the regime failed to elaborate a coherent great-power ideology interlaced with the dramatic historical context. History books developed on the instruction of the Kremlin represented an important attempt to form a narrative based on state ethnicism in the setting of a "besieged fortress." Nevertheless, the regime probably never decided what part of the Soviet legacy is more advantageous to protect. Thus, even in textbooks opposing "vilification" of the Soviet Union, its regression is explained, in the first instance, by systemic pathology, but not by influence of external forces. Despite the anti-western pathos, the authors were guided by defensive nationalism, but not revanchism and neo-imperialism (Sherlock, 2012).

Combination of the past and present, significance of past historical events in assessment of the present testify the important role of historical memory.

Historical memory has a potential to aggravate or diminish perception of events taking place in private and public life, exacerbate negative characteristics, facilitate calming the public and group behavior. Such instability and paradox of consciousness is aggravated by the fact that historical memory, as well as the results of some historical researches, is utilized in current political and ideological rhetoric and engaged by various political forces. Many artificial models of interpretation of the past are emotionally colored and somewhat stimulate thinking by analogy, trying to explain current problems from "methodological" point of view of conceptual and ideological antiquity that sometimes oddly coexists with various pseudo-scientific theories. 
Historian V. Nadein was quite tough, but fair writing that the process of concealing abominations by a cover of sanctity is now called "consecration". October 1917, Red Cavalry, collectivization, defeat of the Trotskyite-Bukharin block were considered sacred. All these fell into oblivion and turned into jokes. A major part of the state lies is already exposed, but the other has not yet been disclosed. Villainous industrialization that plunged three generations into poverty still gets new points on the scale of historical achievements. The atomic bomb allegedly saved us from American occupation. The first spaceflight proved our global scientific leadership. In addition, the war, of course, is the most important thing. The ruling team and, above all, V. Putin desperately need boosting their legitimacy. They feather own nest with both Monomakh's Cap, Yuri Gagarin's space suit, and the horse of Marshal Zhukov. Stalin managed to deform the story to his own preferences. He needed two crucial elements for this purpose. The first: the theorist, historian, Professor M. Pokrovsky. Thanks to his efforts, the name of Stolypin in Russian history is associated with "Stolypin's neckties" only (TN: Russian metaphor for hangman's noose). The second: practical historian L. Beria. He was the one who had sent schoolteachers to concentration camps "for discrediting the national public figure Ivan the Terrible." If the practical historian is more or less effective without theory, the theories of Pokrovsky without Beria's practice were just unalive. Putin has no Beria at command. Moreover, he might regret about this in future. However, now we have to find a way out of troubles using available means. Churov's veil did not cover the emperor with no clothes. For this purpose, it is necessary to invent a tunic made of historical legitimacy as soon as possible. It does not matter if it would be myths, rumors, or gossips. The main thing is to come closer to famous statement attributed to Stolypin: "Give me 20 years of calm, and I will reform Russia" (Nadein, 2012).

We have to admit that the "constructed historical past" in the modern Russian society remains unsteady. Controversies with regard to the historical past result from absence of consistency in opinions on the desired future of the country. Historical narrative of power is being formed and is preconditioned by its political pretensions and ideological motivations.

\section{Discussion}

Thus, social memory transformation in the Russian society in a general way includes its deformation in locus of relationship between the past and present.

The difference between history and historical memory as an integral part of social memory resides in the way of interpreting the possibility to perceive the past time. Deformations of social memory in locus of relationship between the past and present relate to the fact that memory is selective and often personified in nature, when evaluation of specific historical figures forms certain impressions, judgments, and opinions.

Social mythogenesis in locus of relationship between the past and present is interlocking with the technologies of social manipulation. Conventional sociocultural reality resides in expansion of administrative influence for the purpose of political mobilization followed by introduction of new information and communication technologies used in everyday political practice under conditions of the information society formation.

Deformations of social memory in locus of relationship between the past and present are predetermined by painful experience of the past. Painful experience of the past and unwillingness to criticize it provokes the issue of history falsification, when any conflict violating the usual course of social and political life, outlining both preparedness to the future and inability to break the chains of the past, emphasizes complexity of experiencing the past in terms of the present.

Paradoxical combination of the past and present, as well as significance of the past events for orientation in the present, show that historical memory is a powerful, active phenomenon that has an impact on people's behavior equal to the influence exerted by estimate of their current economic situation, their insecurity and despondency in this transitional period. However, the "constructed historical past" in modern Russian society remains unsteady. Controversies with regard to the historical past result from absence of consistency in opinions on the desired future of the country. Historical narrative of power is being formed and is preconditioned by its political pretensions and ideological motivations.

\section{Reference}

Assman, J., \& Beck, C. H. (2000). Religion and kulturelles Gedächtnis. München: Verlag.

Anikin, D. A. (2008). Space of social memory. Saratov: Saratov State University.

Bloshenko, E. V. (2011). Archaic myths of the Russian social reality (p. 138). Molodoy Ucheny, Chita.

Dubin B. et al. (2006) Revival of unenchanted ghost. Stalin and anti-Stalinism: Discussion materials. Retrieved from http://www.polit.ru/article/2006/03/06/antistalinizm/ 
Connerton, P. (2009). How Modernity Forgets. NY: Cambridge University Press.

Dolgikh, V. I. (2012). About the objectives of veterans' organizations to strengthen the fight against counterfeiters of history. Moscovskiy Veteran, 13-14, 416-417.

Dondurey, D. (2010). The Stalin Myth: Reproduction Technology (Vol 4, pp. 17-20). Iskusstvo Kino.

Durkheim, E. (2010). The Division of Labor in Society. NY: Free Press.

Douglas, M. (1986). How Institutions Think. Syracuse, NY: Syracuse University Press.

Erll, A. (2008). Literature, Film, and the Mediality of Cultural Memory. Cultural Memory. In A. Erll, \& A. Nunning (Eds.), An International and Interdisciplinary Handbook (p. 392). Berlin, NY: De Gruyter. http://dx.doi.org/10.1515/9783110209310

Gudkov, L. (2008, February 21). Historical Impotence. Novaya Gazeta.

Kleitman, A. (2009). Oblivion as a cultural phenomenon and subject temporality. Fundamental problems of cultural studies. In D. L. Spivak (Ed.), Anthology of articles from congress materials. Moscow: Noviy Hronograf.

Korolev, S. A. (2005). "National idea" as an instrument of electoral impact: managed democracy in search of ideological support. In Putin's regime: The ideas and practices. M.: Sekachev.

Linde, Ch. (2009). Working the past: Narrative and Institutional Memory. NY: Oxford University Press. http://dx.doi.org/10.1093/acprof:oso/9780195140286.001.0001

Linde, Ch. (1993). Life Stories: The Creation of Coherence. NY: Oxford University Press.

Lowenthal, D. (1985). The Past is a Foreign Country. Cambridge: Cambridge University Press.

Lowenthal, D. (1998). The Heritage Crusade and the Spoils of History. Cambridge: Cambridge University Press. http://dx.doi.org/10.1017/CBO9780511523809

McAuley, M. (2011, January-April). Historical Memory and Society of Citizens (p. 134). Proet Contra.

Nadein, V. (2012, May 25). Stolypin, Putin, Mikhalkov. Part two. Cast no dirt into the holy well! In Ezhednevmiy Zhurnal. Retrieved from http://www.ej.ru/?a=note\&id $=11812$

Podlipskiy, V. V. (1997). Fundamentals of the metaphysics of history (Vol 2, p. 110, p. 123). Metaphysicheskiye Issledovaniya: Saint Petersburg State University

Pomortseva, A. M. (2009). Civilizational fault (challenge) and archaic style of human consciousness (response). Bulletin of Stavropol State University, 61, 46-48.

Solopova, O. A. (2006). Metaphoric modeling of the past, present and future vision in terms of parliamentary elections in Russia (2003) and the United Kingdom (2001). Ekaterinburg.

Svyatoslavsky, A. V. (2012). Life environment as a memory medium: Back to the history of domestic memorial culture. Moscow: Moscow State Pedagogical University.

Sherlock, T. (2012). How the US and Russia treat their unsightly history. Retrieved from http://www.globalaffairs.ru/number/Opyt-lakirovki-istorii-15466

Toshchenko, J. T. (2010, May 13-14). Mankurtism as a form of historical amnesia. In Dialogue of Cultures and Partnership of Civilizations: Formation of Global Culture (p. 225). The Russian Academy of Science.

Zelizer, B. (1995). Reading the Past against the Grain: The Shape of Memory Studies. Critical Studies in Mass Communication, 12(2), 214-239.

Zvereva, G. (2005). The Eternal War. Kriticheskaya Massa.

\section{Copyrights}

Copyright for this article is retained by the author(s), with first publication rights granted to the journal.

This is an open-access article distributed under the terms and conditions of the Creative Commons Attribution license (http://creativecommons.org/licenses/by/3.0/). 